\title{
A study on the effect of organizational climate on organizational commitment: A case study of educational system
}

\author{
Bahman Saeidipour*
}

Professor of Educational Sciences of Payame Noor University, I. R. of Iran

\section{H R O N I C L E \\ A B S T R A C T}

Article history:

Received June 28, 2012

Received in revised format

26 October 2012

Accepted 10 November 2012

Available online

November 122012

Keywords:

Organizational climate

Organizational commitment

Continuous commitment

Affective

Normative

Organization

\begin{abstract}
Building strong commitment among organizational employees plays an important role in reducing delays and displacement. It can also increase employee efficiency, employees' mental freshness and manifesting both organizational admirable targets and personal goals. The purpose of this study is to detect and to forecast the impact of organizational climate on level of organizational commitment among staff education in city of Kermanshah located in west part Iran. The survey designs questionnaires and collects necessary information using a descriptive survey. The statistical population includes all 921 employees who were either enrolled in administration level or work as teacher in all areas of city of Kermanshah. The study selects 300 individuals from the statistical population randomly. The proposed model of this paper uses factor analysis to determine the most important factors influencing organizational commitment and Cronbach alpha is used to validate the results. The results show that there is a significant relationship between the components of role and paying enough attention to goals, the variable organizational climate, and the whole variable dimensions of organizational commitment. The other observation is that there was a weak relationship with some components of social commitment, and there was not any significant relationship with other aspects. Results of multivariate regression analysis shows that there was a high correlation between organizational climate and social commitment (t-student=6.208).
\end{abstract}

\section{Introduction}

Organizational climate and commitment are the most important issues in any organization. Commitment can be promoted or improved through a specific selection of employees, monitoring job, educational reasoning, and organizational socialization (O'Reilly et al., 1990). Organizations are considered as major parts of today's society and human being needs for survival and living are planned through. In fact, many people state our society as an organizational society where people are born, educate, work and die (Baugh \& Roberts, 1994; Saburi, 2004).

\footnotetext{
*Corresponding author.

E-mail addresses: bahman_saeidipour@yahoo.com (B. Saeidpour)
} 
Security is one of the most important components of organizational commitment and lack of organizational commitment could create job stress, inefficient and long working days. In the context of increasingly unstable economic conditions, it is important for managers to setup good background for improving organizational commitment (Giddens, 2010). On the other hand, low levels of discipline, confidence and responsibility are created in organization under the circumstances of the contemporary world, which influence employee commitment. In other words, it is important to build a mutual trust between employer and employee to increase organizational commitment. Human resources are the primary component of any organizations and it is important to make any changes within the organizations to increase their commitment. Azad and Sadeghi (2012) indicated four factors influencing organizational commitments. The first factor is associated with cultural factor, the second issues are human resource based factors while the third factor is related to the behavior based factors and finally empowering based factors are the last item. They used structural equation modeling and the results showed that the third factor, behavior based components, was the most important factor followed by the second factor, human resource factor. In addition, the third important factor was cultural issues followed by empowering factors.

Bahramzadeh and Khosroabadi (2012) investigated the relationship between organizational commitment and knowledge sharing in a case study of university employee cooperation. They discussed that knowledge sharing is an important item on helping organizations reach their objectives, it helps distribution of overall awareness among workers and creates better environment for adding more value. There are literally various factors impacting knowledge sharing and organizational commitment is one of the most important items. They presented a study in one of privately held universities located in city of Bojnourd, Iran and selected a sample size 145 out of 236 people from both regular employees and university professors and used various tests such as Pearson correlation test to investigate the results. The proposed model of the paper confirmed that there was a positive and meaningful relationship between these two components when the level of significance was set to five percent. The results of this survey also disclosed that while ethical commitment and normative played important impact on knowledge sharing, continuity had no significant effect on knowledge sharing within organization. The other observation is that while gender and age had no effect on knowledge sharing, higher educational background was an important factor on knowledge sharing.

Abid et al. (2012) explored the authentic leadership styles of an entrepreneur and its effects on employee's commitment and satisfaction. By using the authentic leadership model, this study looked to give a tentative test of the connection among employees' awareness of the business creator as an authentic leader and the employees' attitudes. Findings were that the opinion of employees' about authentic leadership serves as the intoxicating analyst of employee job satisfaction and organizational commitment. Nazeri et al. (2012) analyzed the impact of the staff's wellbeing stated as independent variable and the work locus of control as the moderator factor related to the organizational commitment and the staff's wellbeing. To accomplish the objective, they implemented regression analysis and concentrated on the one's capability to forecast the staff's wellbeing and it investigated the impacts of the work locus of control as a moderator on the organizational commitment. They explained that the staff's wellbeing maintained a negative relationship with the continuance commitment and a positive relationship with the affective and normative commitments. Moreover, the effect of the work locus of control, as moderator, on the relationship between the staff's wellbeing and their organizational commitment relational and had some necessities.

Iravani (2012) explained that job satisfaction could have sustainable growth in any business units. In fact, he explained that when an unsatisfied employee leaves, the business unit not only loses an employee but also it loses an intangible asset. Therefore, it is essential to evaluate overall job satisfaction occasionally and provide some guidelines for improving work conditions. They investigated a case study and reported that there were some positive relationships between job 
satisfaction and other factors including wage increase, psychological needs, physical equipments, entertainment equipment and work-team. The purpose of this study is to compare organizational commitment with organizational climate components. In line with this goal, the partial goals are as follows,

1-Cognition organizational climate of staff education of Kermanshah

2-Cognition the organizational commitment of staff education of Kermanshah

3-Determine the effect of organizational climate on organizational commitment

Santos (1998) studied related factors with job commitment, organizational, and professional of teachers of development organization in the Dominican Republic and reported that there were positive and significant relationships between job prestige and job commitment, organizational credibility and job commitment, professional reputation and job commitment. Tsai and Wang (2004) investigated the role of pay satisfaction as an intervening variable, on relationship between organizational commitment and professional and studied the important factors influencing on professional and organizational commitment. They reported a positive and significant relationship between professional commitment and organizational.

Jacobus (1994) investigated the relationship between organizational climate, management development and job satisfaction of teachers where the goal was to determine important factors increasing the performance of a teacher as a skilled worker. The results showed that a positive organizational climate effectively through motivate teachers to do their educational functions, makes it easy to management work and the ability of teachers to achieve its goals be encouraging and increases (Jacobus, 1994).

A set of internal characteristics, which distinguish three offices of education and administration of city of Kermanshah from each other and the impact of the behavior on their members is called organization climate. To be more precise, climate is defined as relatively stable quality office environment where employees have good experience with. Climate influences employees' behaviors and it is based on the collective perceptions of behavior in an organization. Tagore (1968) defined organizational climate as organizational climate, comprehensive quality indoor the organization, which is experienced by members, affect on their behavior, and it could be the organization special characters (Khoshakhlaq, 1996; Greenberg, 2004).

\section{Approaches to organizational climate}

The structural approach: In this approach, basically, organizational climate considers different features depending on organization. The features are associated with organization, and they are independent of their members. According to this approach, organizational structure plays important role and independent of perception of membership of the organization, in the formation of organizational climate.

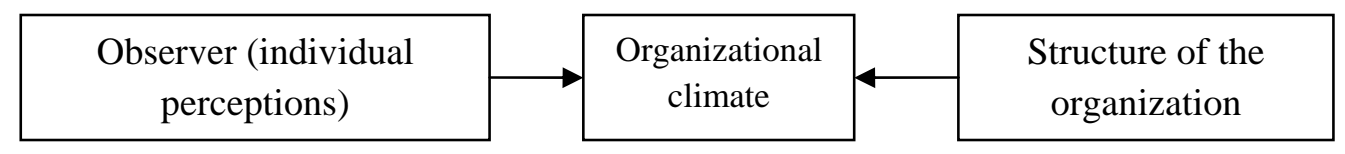

Fig. 1. The process of formation of organizational climate in the structural approach The Perceptual Approach: According to this approach, fundamental of organizational climate knows the members of the organization. The perceptual approach is based on the premise that people, the situational variables in a way that is meaningful to them in terms of psychology exegesis and interpretation and respond that. So the climate is dependent on employee perceptions (See Fig. 2). 


\begin{tabular}{|c|c|c|} 
Organizational climate & $\begin{array}{c}\text { Observer (individual } \\
\text { perceptions) }\end{array}$ \\
position
\end{tabular}

Fig. 2. The process of formation of organizational climate, in the perceptual approach of the organizational position

The Interaction Approach: According to this approach, organizational climate is the result of interaction between organization members and organizational positions. Interaction approach can be demonstrated as follows,

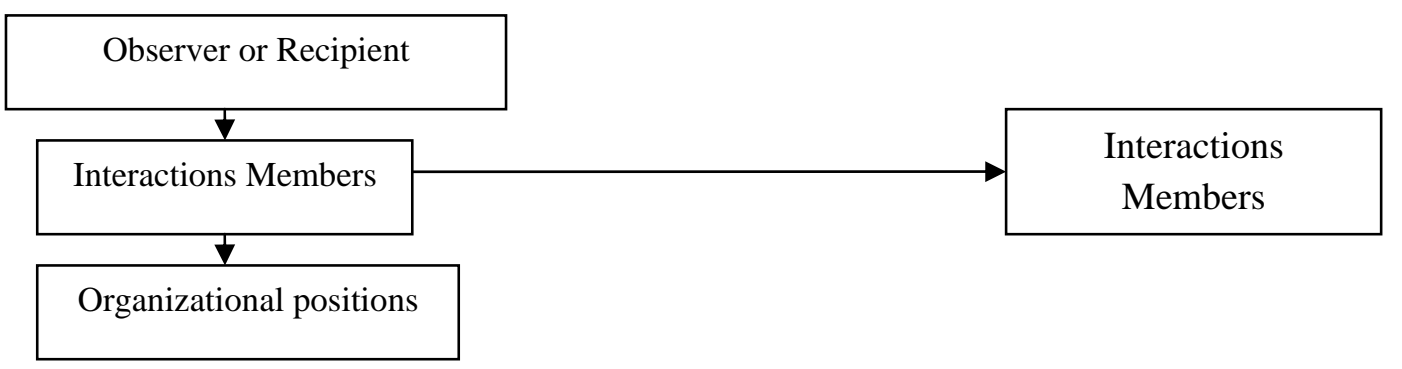

Fig. 3. The process of formation organizational climate in Interaction approach

The Cultural Approach: According to this approach, organizational groups create a shared sense of values, goals, targets, which are the results of collective interpretation. In this approach, organizational climate is considered as a particular part of the culture.

\section{Organizational commitment}

Organizational commitment is an index of individual loyalty to the organization (Robbins, 1977). Porter et al. (1974) defined organizational commitment, the relative degree of personal identification with the organization and other participation to the organization, which has the following components: 1 - believe to the organization's goals and values. 2 - The tendency to extreme effort in the way of organization. 3 - A deep desire to continue membership in the organization. Summers and Hendrix (1991) explained organizational commitment as a kind of dependence and annexation to the organization, which would present as acceptance values of the organization, and willingness to remain in the organization (Summers \& Hendrix, 1991; Allen \& Meyer, 1990). Parsons and Smelser (1950) introduced commitment, as boundary maintenance, system of action of, members of an organization. Becker (1960) introduced commitment as a factor for determining the stability behavior of human.

\subsection{The main hypothesis of this study}

Employees' organizational commitments, which have favorable deduction of the organizational climate (open climate) is higher than other employees.

Sub-hypotheses:

1 - There is a significant relationship between organizational climate and organizational commitment. 2 - People's degrees have significant effects on employees' organizational commitment.

3 - Record of service of employees has a significant effect on their organizational commitment.

\subsection{Research Methodology}

The purpose of this study is to detect and to forecast the impact of organizational climate on the level of organizational commitment among staff education of the city of Kermanshah located in west part Iran. The survey designs questionnaires and collects necessary information using a descriptive 
survey. The statistical population includes all 921 employees who were enrolled in either administration level or work as teacher in all areas of city of Kermanshah. The study selects 300 individuals from the statistical population randomly and the questionnaire consists of 20 questions.

To measure organizational climate we use organizational climate questionnaire designed by Sussman and Deep (1989). This questionnaire contains 20 questions, which are designed in a range of fivepoint Likert and organizational climate variables measured in five dimensions or components. The components are based on organization's goals, organizational role, organizational rewards, organizational procedures and organizational communication. Each of these components can be measured by using four questions.

Organizational commitment: The commitment that leads to desirable organizational outcomes such as higher performance, lower abdication. The questionnaire consists of three components:

1. A robust interest for survive member of a special organization, which is known as affective commitment.

2. Tend to try a lot for organization, which is known as normative commitment.

3. A firm belief in accepted values and goals of organization is expressed as continuous

Each of these components of organizational commitment is measured by using five questions in a seven range that one end of the spectrum start from score of zero and the other end of the spectrum ends to score of six. It should be noted, the minimum possible score for this variable is zero, and the maximum is 90 . High Score indicated higher commitment of people to the organization. In this study for this purpose was used of Cronbach's alpha coefficient. The following questions are come to introduced, where $\mathrm{X}$ denotes the question of the table.

Goals of the organization are clear to me (X1). I can influence on organizational goals, and as it is my favorite, I directed it (X2). Goals of the organization are full manifestation of my dreams, about the organization (X3). All of members of the organization are working towards the same goals (X4). The special role in the organization is my responsibility and it is clear to me (X5). My role in the organization is clear to others (X6). The roles of others in the organization are clear to me (X7). I play an important role in organization and I am satisfied with (X8). I receive rewards proportion to my contribution to organization (X9). When I am motivated I will contribute more on organization (X10). Members of the organization support the organization and receive appropriate rewards (X11). In my opinion, being a member of this organization satisfies me (X12). Decisions are taken in an effective mode (X13). Disagreement in the organization can solve an efficient manner (X14). When issues are discussed to everyone, people will be given the opportunity to present their views (X15). In general, I agree with the current method of doing things (X16). I am aware of the issues related to my jobs (X17). I have the ability to transfer enough information to others (X18). Organizational members believe what they really feel about issues and events can be transferred to other people (X19). I get enough feedback from others about my performance (X20).

After determining the number of factors, we need to know what questions belong to which factor and we use rotation factor matrix to detect it. Bartlett's test results, caused by correlation matrix among questions of organizational commitment variables show that there were three dimensions. Therefore, questions available in an aspect have significant correlation with the other questions in that aspect. However, the existing questions in other dimensions of this variable have either no significant correlation or the correlations are weak. Kaiser Meyer test KMO is 0.862, which is significant at 95 percent so it is not necessary to remove any questions from this collection. Bartlett's sphericity test with the 1818.057 at least 95 percent of confidence is significant. 
Table 1

Rotation factor matrix of components of organizational climate variables

\begin{tabular}{|c|c|c|c|c|c|}
\hline Questions & $\begin{array}{c}\text { Factor } 3 \\
\text { (reward agreement) }\end{array}$ & $\begin{array}{c}\text { Factor } 2 \\
\text { (role agreement) }\end{array}$ & $\begin{array}{c}\text { Factor } 1 \\
\text { (goal agreement) }\end{array}$ & $\begin{array}{c}\text { Factor } 5 \\
\text { (agreement Communications) }\end{array}$ & $\begin{array}{c}\text { Factor } 4 \text { (agreement } \\
\text { procedures) }\end{array}$ \\
\hline $\mathrm{X} 1$ & & & 0.762 & & \\
\hline X2 & & & 0.581 & & \\
\hline X3 & & & 0.847 & & \\
\hline $\mathrm{X} 4$ & & 0.871 & & & \\
\hline $\mathrm{X} 5$ & & 0.591 & & & \\
\hline X6 & & 0.761 & & & \\
\hline $\mathrm{X7}$ & & 0.705 & & & \\
\hline $\mathrm{X} 8$ & & 0.568 & & & \\
\hline $\mathrm{X} 9$ & 0.805 & & & & \\
\hline $\mathrm{X} 10$ & 0.283 & & & & \\
\hline $\mathrm{X} 11$ & 0.460 & & & & \\
\hline $\mathrm{X} 12$ & 0.419 & & & & \\
\hline $\mathrm{X} 13$ & & & & & 0.817 \\
\hline $\mathrm{X} 14$ & & & & & 0.681 \\
\hline $\mathrm{X} 15$ & & & & & 0.380 \\
\hline $\mathrm{X} 16$ & & & & & 0.586 \\
\hline $\mathrm{X} 17$ & & & & 0.711 & \\
\hline $\mathrm{X} 18$ & & & & 0.424 & \\
\hline $\mathrm{X} 19$ & & & & 0.987 & \\
\hline $\mathrm{X} 20$ & & & & 8700. & \\
\hline
\end{tabular}

Table 2 shows the initial statistics for factor analysis in the organizational commitment variable. As is evident, Eigenvalue of three factors is relatively high, therefore, these three items are the best factors for analysis and all three factors explain the most variance of the desired range. Table 2 shows details of the questions: I am willing to do anything for the success of organization (X1). When I am talking with my friends about my organization I understand that it is a great organization to work for (X2). I have felt very little loyalty to this organization (X3). I have accepted approximately every type of job duty in order to keep my job in this organization (X4). I have realized that my values are very similar with organization values (X5). I am proud to tell others that I am part of this organization (X6). I have to do working on another organization too as long as the kind of work that I do similar work in both organizations (X7). The organization really blows in my spirit the inspiring to have high job performance (X8). If I have little impact on organization, I will leave the organization (X9). I am very happy that I chose the organization to work, whereas I have conditions of joining, to other organizations (X10). By joining this organization, I did not get the achievement of very important (X11). Most organizational policies that is relevant to the position of staffs of organization do not comply with my wishes (X12). I am really worried about fate of the organization (X13). The organization that I am working for now is better than all possible organizations (X14). My decision to work for this organization was a clear mistake (X15).

Table 2

Rotated Factor Matrix

\begin{tabular}{cccc}
\hline Questions & Factor 2 (continuous commitment) & factor 3 (normative commitment) & Factor 1 (affective commitment) \\
\hline X1 & & & 0.996 \\
X2 & & & 0.554 \\
X3 & & 0.725 & 0.465 \\
X4 & & 0.665 & 0.364 \\
X5 & & 0.548 & \\
X6 & & 0.352 & \\
X7 & & 0.432 & \\
X8 & & & \\
X9 & 0.982 & & \\
X10 & 0.975 & & \\
X11 12 & 0.895 & & \\
X13 & 0.769 & & \\
X14 & 0.394 & & \\
X15 & & & \\
\hline
\end{tabular}




\subsection{Presentation and analysis of data}

In this section, we investigate the data associated with social - economic characteristics of respondents and their distribution. Most of the respondents maintained a bachelor's degree (56.3\%), $20.7 \%$ had two years university educations, $11.3 \%$ finished high school and less than $12 \%$ had fewer years of educations. It also showed that $63.0 \%$ were in bachelor positions, $30.3 \%$ were liable expert, $5.3 \%$ were enrolled as assistant expert position. The average of age of study subjects is equal to 41.070 years, and the average record of service of employees was equal to 21.45 years. Table 3 shows the mean scores of the respondents from organizational commitment variable each of the three steps of it, and also mean score of respondents from independent variable of organizational climate, and each of its five steps. Organizational commitment mean score for subjects is equal to 46.816 and the score is in higher level compared with score range (0 to 60). First indicator of organizational commitment in this study is affective commitment, mean score for the following subjects is equal to 14.823 and this score is in higher level compared with domain score (0 to 16). The second indicator of organizational commitment in this study is normative commitment and its mean score for subjects is equal to 16.44 , which is relatively high compared with score range (0 to 16 ) and indicates existence of a high normative commitment among employees. The third indicator in the table is continuous commitment and its mean score for subject is equal to 15.54. This score is in the highest level compared with score range ( 0 to 16 ) and it indicates high continuous commitment among staff and respondents.

Another variable in this category is organizational climate. These variables are reported in Table 3 in terms of five indicators based on the organizational goals, role of reward, people's roles, procedures and organizational communications. Each of the five dimensions as been measured by using four questions, in the form of seven- range Likert scale. Total average of organizational climate in this collection for subjects is equal to 51.723 and this score is relatively in low level compared with the score range ( 0 to 120$)$. The first indicator of the organizational climate variable, organizational goals, for subjects the average score for subjects is calculated as 8.726, which is in low level than score range (0 to 24). The second indicator of the organizational roles variable is the organizational roles where the average score for subjects is equal 10.023 and this score has been in the modest level compared with score range (0 to 24$)$. The third indicator of organizational climate variable is organizational rewards and the average score for subjects is equal to 9.660. This score has been in low level compared with score range (0 to 24). Fourth organizational climate variable indicator is considering organizational procedures and the average score for this subjects is equal to 10.803 . This score has been in modest level compared with score range (0 to 24). Fifth indicators of organizational climate variable is considering organizational communication and the average score for subjects is equal to 12.510 where this score has been in high level compared with score range (0 to 24).

\section{Table 3}

The relative distribution of organizational climate indicators and organizational commitment and dimensions of every one

\begin{tabular}{|c|c|c|c|c|c|}
\hline Variable name & Dimensions variable & Frequency & Mean & $\begin{array}{l}\text { Standard } \\
\text { deviation }\end{array}$ & $\begin{array}{c}\text { Cronbach's } \\
\text { alpha }\end{array}$ \\
\hline \multicolumn{2}{|c|}{ Organizational commitment } & 300 & 46.816 & 9.536 & 0.73 \\
\hline \multirow{3}{*}{$\begin{array}{l}\text { Organizational } \\
\text { commitment }\end{array}$} & First dimension: affective & 300 & 14.823 & 4.662 & 0.66 \\
\hline & second dimension: normative & 300 & 16.446 & 4.154 & 0.71 \\
\hline & The third dimension: continuous & 300 & 15.546 & 3.934 & 0.79 \\
\hline \multicolumn{2}{|c|}{ organizational climate variable } & 300 & 51.723 & 12.512 & 0.79 \\
\hline \multirow{5}{*}{$\begin{array}{c}\text { organizational climate } \\
\text { variable }\end{array}$} & First dimension: organizational goals & 300 & 8.726 & 3.422 & 0.68 \\
\hline & Second dimension the role of reward & 300 & 10.023 & 3.725 & 0.77 \\
\hline & Third dimension: roles of individuals & 300 & 9.660 & 3.844 & 0.75 \\
\hline & fourth dimension: Procedures & 300 & 10.803 & 4.082 & 0.37 \\
\hline & Fifth dimension: Communication & 300 & 12.510 & 3.077 & 0.54 \\
\hline
\end{tabular}




\subsection{Testing the hypotheses}

Testing research hypotheses was performed by using statistical techniques such as correlation coefficient, ANOVA and Friedman test. Table 4 shows correlation coefficient between organizational climate variable and organizational commitment. The results of the Pearson correlation coefficient indicates that there is a significant relationship between the two variables $(r=0.50)$. Due to the significant level of the table that is equal to 0.000 and comparing the results with allowable error 0.05 ( $\mathrm{p}<0.05$ ) with $95 \%$ confidence the $\mathrm{H}_{1}$ hypothesis is confirmed, which means there is a significant relationship between organizational climate and organizational commitment. Also correlation coefficient between age variable and organizational commitment ( $\mathrm{r}=0.04)$ shows that there is no relationship between the two variables. Due to the significant level of the table, which is equal to 0.842 and comparing the results with allowable error $0.05(\mathrm{p}<0.05)$ the $\mathrm{H}_{1}$ hypothesis is rejected with 95\% confidence means there was no significant relationship between age of the respondents and organizational commitment. Based on the results of the correlation coefficient between record of service variable and organizational commitment $(\mathrm{r}=0.020)$, it can be said that there is no significant relationship between them since the significant level of the table that is equal to 0.73. Comparing the results with allowable error 0.05 , the $\mathrm{H}_{1}$ hypothesis is rejected with $95 \%$ confidence. It means there was no significant relationship between record of service variable of respondents and organizational commitment.

Table 4

Correlation coefficient between organizational climate variable and organizational commitment

\begin{tabular}{clcccc}
\hline & Variable name & Mean & standard deviation & correlation coefficient & Sig. \\
\hline \multirow{2}{*}{ Organizational } & Variable of organizational climate & 51.723 & 12.512 & 0.50 & 0.000 \\
\cline { 2 - 3 } & Age & 41.070 & 11.317 & 0.04 & 0.947 \\
& Record of Service & 21.45 & 6.58 & 0.020 & 0.703 \\
\hline
\end{tabular}

Table 5 examines the relationship between three indicators of social commitment including affective, normative and continuous and organizational climate with goals, roles, rewards, procedures, and communication. The results show that there were significant relationships between components of role and attention the goals, in organizational climate variable, and the total dimensions of organizational commitment variable in other dimensions there was a weak relationship with some of components of social commitment, and with other dimensions is not significant relationship.

Table 5

Correlation matrix between social commitment variable and organizational climate

\begin{tabular}{|c|c|c|c|c|c|}
\hline \multicolumn{3}{|c|}{$\begin{array}{l}\text { Components of organizational climate and social effective } \\
\text { commitment }\end{array}$} & Normative & Continuous & $\begin{array}{l}\text { Organizational } \\
\text { commitment }\end{array}$ \\
\hline \multirow[t]{2}{*}{ Component of goals } & Amount of correlation & 0.178 & 0.285 & 0.195 & 0.293 \\
\hline & Significance level & 0.002 & 0.000 & 0.001 & 0.000 \\
\hline \multirow[t]{2}{*}{ Component of role } & Amount of correlation & 0.239 & 0.323 & 0.227 & 0.351 \\
\hline & Significance level & 0.000 & 0.000 & 0.000 & 0.000 \\
\hline \multirow[t]{2}{*}{ Component of reward } & Amount of correlation & 0.119 & 0.144 & 0.102 & 0.163 \\
\hline & Significance level & 0.039 & 0.012 & 0.077 & 0.005 \\
\hline \multirow[t]{2}{*}{ Component of procedure } & Amount of correlation & 0.008 & 0.146 & 0.177 & 0.140 \\
\hline & Significance level & 0.893 & 0.012 & 0.002 & 0.015 \\
\hline \multirow{2}{*}{$\begin{array}{l}\text { Component } \\
\text { communication }\end{array}$} & Amount of correlation & 0.052 & 0.283 & 0.211 & 0.236 \\
\hline & Significance level & 0.372 & 0.000 & 0.000 & 0.000 \\
\hline \multirow[t]{2}{*}{ Organizational climate } & Amount of correlation & 0.172 & 0.336 & 0.262 & 0.338 \\
\hline & Significance level & 0.003 & 0.000 & 0.000 & 0.000 \\
\hline
\end{tabular}

Based on the results of Table 6, the mean scores are 45.00 for below diploma, 43.359 for diplomas, 45.209 2-year college degrees and 48.479 for bachelor degree. Accordingly, there are some significant differences between the scores of organizational commitment in various ethnic groups and 
these differences are based on the F tests are acceptable when the level of significant is Sig $=0.005$. Table 6 shows the mean differences test of organizational commitment in terms of the degree of sample.

\section{Table 6}

The mean differences test of organizational commitment based on the degree of sample

\begin{tabular}{lccccc}
\hline Degree & Frequency & Mean & Standard Deviation & F & Sig \\
\hline below diploma & 35 & 45.000 & 8.174 & & \\
Diploma & 34 & 43.359 & 8.824 & \multirow{2}{*}{4.359} & 0.000 \\
associate degrees & 62 & 45.209 & 8.928 & & \\
licenses & 169 & 48.479 & 9.536 & & \\
\hline
\end{tabular}

Table 7 shows the mean differences test of organizational commitment based on executive position. The mean score is $\mathbf{4 9 . 0 0 0}$ for people in charge, 46.250 for expert helper, 45.486 for expert and 47.505 for liable expert. Accordingly, the difference is very small, based on F test and significant level Sig $=0.811$ at least $95 \%$ is not significant and the hypothesis isn't accepted.

\section{Table 7}

The mean differences test of organizational commitment based on executive position of sample

\begin{tabular}{lccccc}
\hline executive position & Frequency & Mean & Standard Deviation & F & Sig \\
\hline People in charge & 4 & 49.000 & 3.915 & & \\
expert helper & 16 & 46.250 & 9.712 & 0.320 & 0.811 \\
Expert & 189 & 46.486 & 9.733 & \\
liable expert & 91 & 47.505 & 9.330 & \\
\hline
\end{tabular}

\subsection{Mean differences in organizational climate dimensions}

Table 8 shows the results of testing mean comparison of organizational climate dimensions. The results show that there is a significant difference between the mean score of organizational climate dimensions, statistically. The results show that organizational climate mean score for the subjects in aspects of organizational goals is 8.726, for aspects of organizational role is 10.023, for aspect of organizational reward is 9.660, aspects of organizational procedures is 10.803, and the aspects of organizational communication is equal to 12.510. The results show that the differences observed between the mean of each dimension, with each other based on F-test has been confirmed with the amount of 45.613 and a significance level of 0.000 .

\section{Table 8}

The test of mean comparison of organizational climate variable dimensions

\begin{tabular}{lcccc}
\hline $\begin{array}{l}\text { Dimensions of organizational } \\
\text { climate }\end{array}$ & Frequency & Mean & Fisher test & F \\
\hline Organizational goals & 300 & 8.726 & 3.422 & \\
Organizational role & 300 & 10.023 & 3.725 & \multirow{2}{*}{45.613} \\
Organizational rewards & 300 & 9.600 & 3.844 & \\
Organizational procedures & 300 & 10.803 & 4.082 & \\
Organizational communication & 300 & 12.510 & 4.077 & \\
\hline
\end{tabular}

Table 9 shows of Scheffe test and illustrates the fact that the differences are not significant between two dimensions of organizational goals with organizational rewards, organizational reward with goals, organizational role and organizational procedures with organizational role and this difference is from the other dimensions of this variable. The results of the Scheffe test indicated that these differences were more accurate. Negative signs in some numbers indicate that the aspect average is greater than intended aspects. For example, -1.296 in the first row shows that the mean of organizational role as a dimension of organizational climate is more than the mean of organizational 
goals dimension, in the organizational climate. These differences are also evident in other dimensions.

Table 9

Scheffe significant differences test for comparison of the scores of organizational climate dimensions

\begin{tabular}{|c|c|c|c|c|}
\hline Scheffe test & Dimensions & Mean differences & Standard deviation & Sig. \\
\hline \multirow[t]{4}{*}{ 1. organizational goals } & organizational role & -1.296 & 0.297 & 0.001 \\
\hline & organizational reward & -0.933 & 0.297 & 0.044 \\
\hline & organizational procedures & -2.076 & 0.297 & 0.000 \\
\hline & organizational communication & -3.783 & 0.297 & 0.000 \\
\hline \multirow[t]{4}{*}{ 2. organizational role } & organizational goals & 1.296 & 0.297 & 0.001 \\
\hline & organizational reward & 0.363 & 0.297 & 0.829 \\
\hline & organizational procedures & -0.780 & 0.297 & 0.144 \\
\hline & organizational communication & -2.486 & 0.297 & 0.000 \\
\hline \multirow[t]{4}{*}{ 3. organizational reward } & organizational goals & 0.933 & 0.297 & 0.044 \\
\hline & organizational role & -0.363 & 0.297 & 0.829 \\
\hline & organizational procedures & -1.143 & 0.297 & 0.005 \\
\hline & organizational communication & -2.850 & 0.297 & 0.000 \\
\hline \multirow{4}{*}{$\begin{array}{ll}\text { 4. } & \text { organizational } \\
\text { procedures }\end{array}$} & organizational goals & 2.076 & 0.297 & 0.000 \\
\hline & organizational role & 0.780 & 0.297 & 0.144 \\
\hline & organizational reward & 1.143 & 0.297 & 0.005 \\
\hline & organizational communication & -1.706 & 0.297 & 0.000 \\
\hline \multirow{4}{*}{$\begin{array}{ll}\text { 5. } & \text { organizational } \\
\text { communication }\end{array}$} & organizational goals & 3.783 & 0.297 & 0.000 \\
\hline & organizational role & 2.486 & 0.297 & 0.000 \\
\hline & organizational reward & 2.850 & 0.297 & 0.000 \\
\hline & organizational procedures & 1.706 & 0.297 & 0.000 \\
\hline
\end{tabular}

Table 10 shows the results of the Friedman ranking mean test. The result shows that mean of ranks in various dimensions of the organizational climate variable are different.

\section{Table 10}

Comparison mean ranking of various dimensions of organizational climate variable

\begin{tabular}{lccc}
\hline Organizational climate dimensions & Mean ranking & chi-square test & Significant level \\
\hline Organizational goals & 2.25 & & \\
Organizational role & 3.04 & 185.299 & 0.000 \\
Organizational reward & 2.73 & & \\
Organizational procedures & 3.09 & & \\
Organizational communication & 3.89 & & \\
\hline
\end{tabular}

\subsection{Mean differences in various dimensions of organizational commitment}

Table 11 shows mean comparison test, variable dimensions of organizational commitment. The results show a statistically significant difference between the mean scores for the various dimensions of organizational commitment. Organizational commitment Mean score for the study population, from affective dimension is 14.823, from normative dimension are 16.446 and from continuous dimension is 15.546. The differences observed have been confirmed between the mean of each dimension with together based on F-test value of 10.925, and the significant level 0.000 .

\section{Table 11}

Mean comparison test of various dimensions of organizational commitment variable

\begin{tabular}{llllll}
\hline Organizational commitment dimensions & Frequency & Mean & Standard deviation & Fisher test & Significant level \\
\hline Organizational goals & 300 & 14.823 & 4.662 & & \\
Organizational role & 300 & 16.446 & 4.154 & 10.925 & 0.000 \\
Organizational reward & 300 & 15.546 & 3.934 & & \\
\hline
\end{tabular}


The results show that the mean ranks are different together in different dimensions of organizational commitment variables so that, the mean for the organizational commitment in normative dimension is higher than other components. Table 12 shows details of our findings.

\section{Table 12}

Comparison of mean test ranking of various dimensions of organizational commitment variable

\begin{tabular}{lccc}
\hline Organizational commitment dimensions & Mean ranking & Chi-square test & Significant level \\
\hline Effective dimension & 1.89 & 9.389 & 0.009 \\
Normative dimension & 2.13 & & \\
Continuous dimension & 1.98 & & \\
\hline
\end{tabular}

\subsection{Multiple regressions}

In this research, we have used multiple regression statistics based on stepwise method. In this way, various variables are entered into the equation. Since organizational commitment has been measured in terms of three dimensions, so we first performed three regression equations for these dimensions and then for organizational commitment variable, overall was performed regression equation again. The first regression equation is associated with social commitment, in the effective dimension. The only variable entered the regression equation, organizational climate is in terms of the organizational roles. The results show there is a high correlation between these variables and social commitment in effective dimension $(\mathrm{T}=4.248$ Sig. $=0.000)$.

\section{Table 13}

Component of the independent variables into the equation to predict organizational commitment, in effective aspects

\begin{tabular}{llccccc}
\hline & & & \multicolumn{3}{c}{ Effective dimension } \\
\hline \multicolumn{2}{l}{ Climate organizational dimensions } & $\mathrm{R}^{2}$ & $\mathrm{~B}$ & Beta & $\mathrm{T}$ & Sig. \\
\hline Organizational role & & 0.239 & 0.229 & 0.239 & 4.245 & 0.000 \\
\hline Constant $=11.825$ & $\mathrm{~F}=18.046$ & $\mathrm{Sig}=0.000$ & & & &
\end{tabular}

The second regression equation is associated with the dependent variable of social commitment and the relationship was statistically meaningful $(T=4.330$, Sig. $=0.000)$. In the second stage climate in aspects of consider to organizational communication is, entered the equation, $T$ value for this variable is equal to (4.549), in the third step with enter degree $\mathrm{T}$ value is equal to $(\mathrm{T}=2.664)$ and significant coefficient is (Sig.T=0.008). These three variables together can explain the 0.172 of the internal changes of organizational commitment variable from the normative dimension.

\section{Table 14}

Components of independent variables into the equation for the prediction of organizational commitment from normative aspects

\begin{tabular}{lccccc}
\hline & \multicolumn{4}{c}{ Normative dimension } \\
\cline { 2 - 6 } Organizational climate dimensions & $\mathrm{R}^{2}$ & $\mathrm{~B}$ & $\mathrm{~B}$ Bta & $\mathrm{T}$ & Sig. \\
\hline Organizational roles & 0.105 & 0.269 & 0.241 & 4.330 & 0.000 \\
Organizational communication & 0.152 & 0.338 & 0.251 & 4.542 & 0.000 \\
Degree & 0.172 & 1.222 & 0.146 & 2.664 & 0.000 \\
\hline Constant $=8.832$ & $\mathrm{~F}=20.509$ & Sig=0.000 & & &
\end{tabular}

The third regression equation is associated with dependent variable of social commitment from continuous aspect where four variables have entered into regression equation. The first variable is entered into the regression equation, is organizational climate in aspects attention to organizational roles. There is a high correlation between this variable and social commitment in aspects of continuous $(\mathrm{T}=1.913$, Sig. $=0.057)$. In second step organizational climate according to organizational communication aspect has been entered into equation ( $T=2.890$, Sig.= 0.004). In 
summary, the three variables together can explain the 0.172 of the internal changes of organizational commitment variable from the continues dimension.

Table 15

Components of independent variables into the equation for the prediction of organizational commitment from continues aspects

\begin{tabular}{|c|c|c|c|c|c|}
\hline \multirow[b]{2}{*}{ Organizational climate dimensions } & \multicolumn{5}{|c|}{ Continues dimension } \\
\hline & $\mathrm{R}^{2}$ & B & Beta & $\mathrm{T}$ & Sig. \\
\hline Organizational roles & 0.105 & 0.121 & 0.115 & 1.913 & 0.057 \\
\hline Organizational communication & 0.152 & 0.215 & 0.168 & 2.890 & 0.002 \\
\hline Degree & 0.172 & 1.504 & 0.190 & 3.178 & 0.004 \\
\hline Organizational prosedures & 0.172 & 0.146 & 0.151 & 2.460 & 0.014 \\
\hline Constant $=9.218$ & \multicolumn{5}{|c|}{ Sig $=0.000$} \\
\hline
\end{tabular}

The latest regression equation is associated with dependent variable of social commitment. The only variable that entered the regression equation is organizational climate. The results show that there is a high correlation between the variable and social commitment $(T=6.208$, Sig. $=0.000)$. $F$ is significant in the sense that there is a direct linear relationship between the independent variables and the dependent variable.

Table 16

Components of independent variables within equation for predicting organizational commitment

\begin{tabular}{|c|c|c|c|c|c|c|}
\hline & & \multicolumn{5}{|c|}{ Organizational Commitment } \\
\hline Organizational climate & & $\mathrm{R}^{2}$ & $\mathrm{~B}$ & Beta & $\mathrm{T}$ & Sig. \\
\hline Organizational climate & & 0.338 & 0.258 & 0.338 & 6.208 & 0.000 \\
\hline Constant $=33.476$ & $F=38.537$ & & Sig $=0$. & & & \\
\hline
\end{tabular}

\section{Discussion and Conclusion}

The results indicate there is a positive or negative reciprocal relationship, and significant correlation between some of components of the organizational climate. An increase in organizational goals, organizational roles, rewards, organizational, institutional practices, and organizational communication are associated with increased commitment at components of performance and influences continuous commitment. Increase or decrease in mean of one component could be effective in increase or decrease of mean of one or more components of organizational climate. So it is appreciated, managers identify components that are not suitable condition in the organization and its causes and according to interaction effects of components select act more effective and shorter ways according to circumstances of the organization and staff required for the improvement of climate, and achieving its results and best performance. Moreover the results of several studies indicate that inappropriate organizational climate can affect on staff and their performance and thus effectively to achieve organizational goals undesirable effects. The issue is more important, especially in a different environment of education according to governing particular circumstances, nature, goals and special customer and its unique characteristics. The results of the Pearson correlation coefficient confirms that there is a significant relationship between organizational climate and organizational commitment variables $(r=0.50)$. Due to the significant level of the table is equal to 0.000 and comparing the results with allowable error $0.05(\mathrm{p}<0.05)$ with $95 \%$ confidence the hypothesis is confirmed, which means there is a significant relationship between organizational climate and organizational commitment.

The results of the Pearson correlation coefficient, confirmed that there is not a significant relationship between age and organizational commitment $(\mathrm{r}=0.04)$. Due to the significant level of the table is equal to 0.842 and comparing the results with allowable error $0.05(\mathrm{p}<0.05)$ hypothesis is rejected 
with 95\% confidence, which means there is not a significant relationship between respondents and their organizational commitment. The results indicate that mean score of organizational commitment for the subjects is equal to 14.823 in aspects of emotional commitment, in aspects of normative commitment is equal to 16.446 and in aspects of continuous commitment is equal to 15.546. The results showed that the differences observed between the mean of each dimension are different with each other. The results of the study showed that the mean of organizational commitment of respondents, depending on the level of education is different together.

\section{References}

Abid, T., Altaf, M., Yousaf, U., \& Bagram, M. M. M. (2012). Entrepreneur as an authentic leader: A study of small and medium sized enterprises in Pakistan. Management Science Letters, 2(7), 23552360.

Allen, N.J. \& Meyer, J.P. (1990). The measurement and antecedents of affective, continuance and normative commitment to the organization. Journal of Occupational Psychology, 63, 1-18.

Azad, A., \& Sadeghi, S. (2012). An empirical study to determine effective factors on organizational commitment. Management Science Letters, 2(8), 2981-2986.

Bahramzadeh, H., \& Khosroabadi, S. (2012). The relationship between organizational commitment and knowledge sharing: A case study of university employee cooperation. Management Science Letters, 2(7), 2661-2666.

Baugh, S.G. \& Roberts, R.M. (1994).Professional \& Organizational Commitment among engineers: Conflicting or complementing?. Transactions on Engineers Management, 41(2), 108-114.

Rezaeian, A. (1998). Principles of Management, Tehran Business School Press, Tehran University (In Persian).

Becker, H. S. (1960). Notes on the Concept of Commitment. American Journal of Sociology, 66, 3242.

O'Reilly, C. A., III, Chatman, J. A., \& Caldwell, D. F. (1991). People and organizational culture: A profile comparison approach to assessing person-organization fit. Academy of Management Journal, 34, 487-516.

Giddens, A. (2010). Sociology, translated by Hassan Chavoshyan Tehran, Ney Publishing. publication (In Persian).

Greenberg, J. (2004). Stress fairness to fare no stress: managing workplace stress by promoting organizational justice. Organizational Dynamics, 33, 322-365.

Iravani, M.R. (2012). A social work study on job satisfaction. Management Science Letters, 2(4), 1397-1402.

Meyer, J. P., \& Herscovitch, L. (2001). Commitment in the workplace: Toward a general model. Human Resource Management Review, 11, 299-326.

Meyer, J.P., \& Allen, N.J. (1991). Commitment to Organization and Occupations: Extension and test of a three-component conceptualization. Journal of Applied Psychology, 78(4), 538-551.

Moghimi, S.M. (2008). Organization and management of research approach, Tehran, Termeh, (In Persian).

Mowday, R.T. (1998). Reflections on the study and relevance of organizational commitment. Human Resource Management Review, 8(4), 387-401.

Mowdey, R.T., Porter, L.W. \& Steers, R.M. (1982). Organizational Linkage: The Psychology of Commitment Absenteesm and Turnover. New York: Academic Press, 20-22.

Nazeri, A., Meftahi, H., \& Kianipour, R. (2012). Entrepreneur as an authentic leader: A study of small and medium sized enterprises in Pakistan. Management Science Letters, 2(5), 1779-1784.

Neuman, W. L. (1991). Social Research Methods: Qualitative and Qualitative Approaches, UK: Allyn and Bacon Press.

Parsons, T. \& N. Smelser (1950). Economy and Society. Rout Ledge \& Keg and Paul. 
Porter, L.W., Steers, R. M., Mowday, R. T., \& Boulian, P. V. (1974). Organizational commitment, job satisfaction, and turnover among psychiatric technicians. Journal of Applied Psychology, 59, 603-609.

Robbins, S.P. (2001). Organizational Behavior. New Dehli. Prentice Hall ,Inc.

Saruqi, A (1996), organizational commitment and its relationship with leaving the service. Quarterly Journal of Public Administration, 35, 73-65.

Shirazi, A. (1994). Educational Management, Mashhad, Jihade Daneshgahi Publications (In Persian).

Steers, R. M., \& Porter, L.W. (1991). Motivation and work behavior. McGraw Hill Inc, $5^{\text {th }}$ ed., 1991.

Saburi, M. (2004), Sociology of Organizations, Tehran, Shabtab Publishing (In Persian).

Summers, T.P. \& Hendrix, W.H. (1991). Modeling the role of pay equity perceptions: A field study. Journal of Occupational Psychology, 64, 145-157.

Tousi, M.A (1991), Organizational Culture, Tehran, Publications Public Administration Training Centre (In Persian).

Tsai, K., and Wang, J. (2004). The R\&D Performance in Taiwan's Electronics Industry: a Longitudinal Examination. R\&D Management, 34(2), 179-189.

Wallace, J. E. (1995b). Organizational and professional commitment in professional and nonprofessional organizations. Administrative Science Quarterly, 40(2), 333-349. 